\title{
PENERAPAN METODE GROUP INVESTIGATION (GI) UNTUK MENINGKATKAN HASIL BELAJAR IPA SISWA KELAS VI SD PENERUS BANGSA KOTA TANGERANG
}

\author{
Candra Puspita Rini ${ }^{1}$, Asep Suherman ${ }^{2}$ \\ candrapuspitarini@gmail.com², asepsuherman@ outlook.com ${ }^{2}$ \\ PGSD, FKIP, Universitas Muhammadiyah Tangerang ${ }^{12}$
}

\begin{abstract}
Abstrak: Penelitian ini bertujuan untuk meningkatkan hasil belajar siswa pada mata pelajaran IPA siswa kelas VI SD Penerus Bangsa Kecamatan Periuk Kota Tangerang. Metode penelitian yang digunakan pada penelitian kali ini adalah Penelitian Tindakan Kelas (PTK) yang terdiri dari empat tahap yaitu perencanaan, pelaksanaan, observasi dan refleksi. Instrument yang digunakan pada penelitian kali ini adalah lembar observasi hasil belajar afektif dan psikomotor. Tes belajar kognitif dan dokumentasi. Hasil penelitian mengungkapkan bahwa terdapat peningkatan hasil belajar kognitif, afektif dan psikomotor pada penerapan metode pembelajaran Group Investigation (GI). Peningkatan hasil belajar IPA siswa terlihat pada hasil penelitian siklus I yaitu rata-rata hasil belajar sebesar 73,77 dengan aspek kognitif sebesar 72,5, pada aspek afektif sebesar 61,76 dan psikomotor sebesar 87,06. Pada siklus II meningkat menjadi 83,64 dengan pembagian aspek kognitif sebesar 83.09 dan afektif sebesar 84,19 dan ketuntasan klasikal kelas sebesar 100\% meliputi kognitif, afektif dan psikomotor.
\end{abstract}

Kata kunci: Group Investigation, IPA.

\section{APPLICATION OF THE GROUP INVESTIGATION METHOD TO IMPROVE RESULTS OF LEARNING SCIENCE 6TH GRADE STUDENTS IN THE PENERUS BANGSA ELEMENTARY SCHOOL OF TANGERANG CITY}

\begin{abstract}
The purpose of this study is to improve student learning outcomes in science subjects of grade 6 students SD Penerus Bangsa Kecamatan Periuk, Tangerang City. The research method used in this research is Classroom Action Research (PTK) which consists of four stages of planning, implementation, observation and reflection. Instrument used in this research is observation sheet of affective and psychomotor learning result. Cognitive learning test and documentation. The results reveal that there is an increase in cognitive, affective and psychomotor learning outcomes in the application of Group Investigation (GI) learning methods. Improvement of students' science learning outcomes is seen in the results of research cycle I ie average learning outcome of 73.77 with cognitive aspects of 72.5, affective aspects of 61.76 and psychomotor of 87.06 . In the second cycle increased to 83.64 with a cognitive aspect
\end{abstract}


Candra, Asep, Penerapan Metode Group Investigation...

division of 83.09 and affective of 84.19 and classical completeness of $100 \%$ class include cognitive, affective and psychomotor.

Keywords: Group Investigation, learning of science.

\section{PENDAHULUAN}

Kemajuan negara beberapa dekade kedepan dapat dilihat dari pendidikan yang sedang berlangsung di suatu negara. Negara maju akan selalu memprioritaskan pendidikan untuk anak-anak di negara tersebut guna investasi pembangunan pada masa mendatang. Indonesia sendiri sebagai salah satu negara berkembang terus berupaya untuk meningkatkan kualitas pendidikan. Tujuan pendidikan nasional mengharapkan hasil belajar yang dipecah kedalam 3 aspek yaitu pengetahuan (Kognitif), Kepribadian (afektif) dan Keterampilan (Psikomotor). Memenuhi 3 aspek tersebut bukan suatu hal yang mudah tetapi juga bukan sebuah hal yang tidak mungkin. Cara memenuhi 3 aspek tersebut adalah dengan meningkatkan kualitas proses belajar.

Pendidikan Ilmu Pengetahuan Alam secara garis besar merupakan gabungan dari ilmu pengetahuan yang menjelaskan gejala fisik yang terjadi di alam semesta. Ilmu pengetahuan tersebut antara lain Biologi, Astronomi, Kimia dan Fisika. Ilmu Pengetahuan Alam di tingkat sekolah dasar lebih menekankan pada membentuk karakteristik serta keterampilan dasar dari konsep ilmu pengetahuan alam. Cakupan Ilmu Pengetahuan Alam juga mempelajarai interaksi berbagai bentuk makhluk dan benda dari yang hanya bisa dilihat oleh mikroskop atom sampai pada benda yang ada di luar angkasa yang besarnya melebihi matahari yang ada di seluruh jagat raya. Pembelajaran Ilmu Pengetahuan Alam akan selalu menghubungkan informasi yang didapatkan di sekolah dengan gejala-gejala kenampakan dan benda-benda yang ada di lingkungan sekitar tempat tinggalnya.

Namun berdasarkan hasil observasi peneliti di kelas VI SD Penerus Bangsa Kecamatan Periuk Kota Tangerang. Masalah yang ditemukan penulis adalah kurangnya variasi penggunaan metode pembelajaran, metode yang digunakan selalu ke arah verbalisme, pembelajaran terlalu berpusat pada guru, kurangnya aktifitas siswa dalam melaksanakanpembelajaran (iklim belajar yang pasif), dan mayoritas siswa belum mampu untuk mencapai KKM dari evaluasi hasil belajar. 


\section{Candra, Asep, Penerapan Metode Group Investigation...}

Selama melaksanakan Observasi data yang didapatkan penulis mulai dari hasil belajar akumulasi setiap siswa di kelas VI dengan nilai rata-rata sebesar 63,76 dari KKM mata pelajaran Ilmu Pengetahuan Alam yaitu 70. Capaian nilai rata-rata siswa tersebut dapat dikategorikan kurang karena masih berada di bawah nilai KKM yang telah ditetapkan. Tabel di atas juga menunjukan hanya 5 siswa yang mendapatkan predikat tuntas dengan presentase $29,41 \%$, sedangkan 12 siswa lain masih belum dapat dikategorikan tuntas dengan presentase $70,59 \%$.

Mata pelajaran Ilmu Pengetahuan Alam terdiri dari banyak materi dan pokok bahasan, salah satunya adalah sistem tata surya. Setiap proses pembelajaran selalu mengharapkan kompetensi yang didapatkan siswa setelah proses pembelajaran berlangsung, sama halnya dengan materi sistem tata surya. Menyampaikan pokok bahasan sistem tata surya membutuhkan metode pembelajaran yang tepat guna menggali informasi secara mandiri. Interaksi antar siswa juga dapat digunakan dalam metode belajar berkelompok sehingga proses mencari informasi lebih efektif dan efisien. Metode yang menuntuk keaktifan siswa dalam mencari informasi sekaligus bekerjasama dalam kelompok adalah metode pembelajaran Group Investigation (GI). Implementasi metode yang tepat akan sangat mungkin mencapai hasil belajar yang diharapkan.

Masalah yang dibahas dalam penelitian ini adalah apakah terdapat peningkatan hasil belajar kognitif, afektif, psikomotor serta iklim belajar yang lebih aktif pada mata pelajaran IPA setelah siswa kelas VI melaksanakan pembelajaran dengan metode Group Investigation (GI). Tujuan dari penelitian ini adalah untuk mengetahui langkah-langkah dan kegiatan yang diterapkan selama melaksanakan metode Group Investigation (GI) serta meningkatkan hasil belajar IPA siswa dalam aspek kognitif, afektif dan psikomotor. Mengupas dan melaksanakan ketiga aspek penilaian dapat lebih menggambarkan berjalannya proses belajar serta berbagai hasil pembelajaran yang didapatkan siswa selama mengikuti proses belajar mengajar.

\section{METODE PENELITIAN}

Pendekatan penelitian yang digunakan penulis adalah Penelitian Tindakan Kelas dengan metode pembelajaran yang digunakan adalah Group Investigation. Pengertian Penelitian Tindakan Kelas (PTK). Pelaksanaan PTK dilakukan secara sistematis yang 
Candra, Asep, Penerapan Metode Group Investigation...

telah direncanakan ke dalam rencana pelaksanaan pembelajaran (RPP) maupun dalam siklus yang dirancang secara ilmiah. Semua langkah dari mulai pelaksanaan yang pada akhirnya bertujuan untuk mencapai sebuah target yang harus dicapai harus dilakukan secara sadar dan dapat dipertanggung jawabkan. Penelitian tindakan kelas dapat melaksanakan penilaian secara menyeluruh baik itu ranah kognitif, afektif dan psikomotor. Memberikan gambaran yang cukup jelas tentang proses pelaksanaan pembelajaran ilmu pengetahuan alam terutama sistem tata surya.

PTK memiliki beberapa model yang dikembangkan oleh beberapa ahli pendidikan salah satunya adalah model penelitian tindakan kelas dari Kemmis dan Mc Teggart. Model Kemmis dan Mc. Teggart ini memiliki empat langkah dalam pelaksanaannya. Empat langkah tersebut adalah Perencanaan (plan), Tindakan dan Observasi (Action \& Observe), dan Refleksi (reflect), dimana tahap tindakan dan observasi akan dilakukan bersamaan. Karena dalam model Kemmis dan Mc. Teggart pelaksanaa tindakan dan observasi dilaksanakan dalam satu kesatuan waktu. Pelaksanaan model penelitian ini penulis merencanakan pelaksanaan penelitian dalam siklus yang dimana setiap siklusnya mencakup keempat tahap peelitian dari Kemmis dan Mc. Taggart sertadirancang dan direncanakan berjalan selama 3 siklus pembelajaran.

Penelitian ini dilaksanakan di SD Penerus Bangsa Kecamatan Periuk Kota Tangerang Banten untuk mata pelajaran IPA. Sebagai Subjek Penelitian ini adalah siswa dan siswi kelas VI yang memiliki jumlah siswa sebanyak 17 siswa yang terdiri dari 7 siswa laki-laki dan 10 siswa perempuan. Alasan penulis melakukan penelitian di tempat ini karena rendahnya hasil belajar siswa pada mata pelajaran IPA dan masih kurangnya pelaksanaan metode belajar yang efektif dan efisien selama melaksanakan kegiatan belajar mengajar di dalam kelas. Pengambilan data yang dilaksanakan peneliti dengan beberapa teknik pengambilan data antara lain observasi, tes tertulis dan tidak tertulis, dokumentasi.

Data yang telah didapatkan penelti berupa data kuantitatif yang nantinya dianalisis data yang bersifat tetap (angka) yang mampu dibuktikan menggunakan logika. Analisis ini memberikan standar yang sama dengan mengolah angka untuk menghitung kenaikan hasil belajar serta keaktifan siswa. Data yang juga diambil yaitu data kualitatif yang digunakan untuk menganalisis dinamika hasil belajar yang diukur 
Candra, Asep, Penerapan Metode Group Investigation...

dengan non tes. Data yang didapatkan akan diberikan predikat secara nyata dan mendalam sesuai dengan masalah penelitian yang dihadapi. Data kualitatif dan kuantitatif akan dibandingkan dengan data yang didaparkan observer dalam penelitian serta dengan dokumentasi selama proses penelitian berlangsung sehingga hasil yang didapatkan dalam penelitian ini menjadi kuat serta lebih jelas.

\section{HASIL DAN PEMBAHASAN}

Penelitian ini dilaksanakan di SD Penerus Bangsa yang beralamat di perumahan Griya Sangiang Mas Jalan Anggrek Nomor 6 - 7 Kecamatan Periuk Kota Tangerang Provinsi Banten. Kelas yang menjadi objek penelitian kali ini adalah kelas VI (Enam) dengan jumlah siswa 17 yang terdiri dari 7 siswa laki-laki dan 10 siswa perempuan. Hasil observasi awal yang didapatkan peneliti ditunjukan pada tabel di bawah ini.

\section{Tabel 1}

\section{Hasil Observasi Prasiklus}

\begin{tabular}{|c|c|c|c|c|}
\hline No & Nama & KKM & Nilai & Keterangan \\
\hline 1 & APS & 70 & 59 & Tidak Tuntas \\
\hline 2 & AHF & 70 & 64 & Tidak Tuntas \\
\hline 3 & CA & 70 & 64 & Tidak Tuntas \\
\hline 4 & EL & 70 & 76 & Tuntas \\
\hline 5 & EK & 70 & 61 & Tidak Tuntas \\
\hline 6 & FMP & 70 & 74 & Tuntas \\
\hline 7 & HK & 70 & 60 & Tidak Tuntas \\
\hline 8 & IPL & 70 & 53 & Tidak Tuntas \\
\hline 9 & JKZ & 70 & 77 & Tuntas \\
\hline 10 & JCS & 70 & 50 & Tidak Tuntas \\
\hline 11 & KAZ & 70 & 73 & Tuntas \\
\hline 12 & NAR & 70 & 80 & Tuntas \\
\hline 13 & N & 70 & 53 & Tidak Tuntas \\
\hline 14 & RA & 70 & 63 & Tidak Tuntas \\
\hline 15 & SA & 70 & 61 & Tidak Tuntas \\
\hline 16 & SD & 70 & 54 & Tidak Tuntas \\
\hline 17 & CW & 70 & 62 & Tidak Tuntas \\
\hline
\end{tabular}

Berdasarkan tabel di atas nilai yang diperoleh 17 siswa, KKM untuk mata pelajaran IPA dan keterangan tuntas dan tidak tuntas dalam capaian hasil belajar. Data menunjukan nilai rata-rata sebesar 63,76 dengan KKM sebesar 70. Capaian nilai ratarata siswa tersebut dapat dikategorikan kurang karena masih berada di bawah nilai KKM yang telah ditetapkan. Tabel di atas juga menunjukan hanya 5 siswa yang 
Candra, Asep, Penerapan Metode Group Investigation... mendapatkan predikat tuntas dengan presentase $29,41 \%$, sedangkan 12 siswa lain masih belum dapat dikategorikan tuntas dengan presentase 70,59\%.

Hasil penelitian siklus I mendapatkan hasil belajar yang didapatkan peneliti sajikan dalam bentuk tabel dengan rekapitulasi data sebagai berikut :

\section{Tabel 2}

\section{Hasil Belajar Siklus I}

\begin{tabular}{|l|l|l|l|}
\hline NO & Aspek Penilaian & Rata-rata Nilai & $\begin{array}{l}\text { Rata-rata } \\
\text { Nilai Akhir }\end{array}$ \\
\hline 1 & Kognitif & 72,5 & \multirow{2}{*}{73,77} \\
\hline 2 & Afektif & 61,76 & \\
\hline 3 & Psikomotor & 87,06 & \\
\hline JUMLAH & & 221,32 & \\
\hline
\end{tabular}

Tabel di atas mendeskripsikan hasil belajar siswa kelas VI SD Penerus Bangsa selama berjalannya penelitian siklus I. Nilai rata-rata akhir yang didapatkan oleh 17 siswa adalah 72,5 dengan nilai rata-rata hasil belajar Kognitif sebesar 72,5, hasil belajar Afektif 61,76 dan hasil belajar Psikomotor 87,06. Data tersebut menunjukan bahwa terdapat peningkatan hasil belajar Kognitif dan Psikomotor walaupun hasil belajar Afektif belum mencapai KKM sebesar 70 .

Tabel 3

\section{Hasil belajar Kognitif}

\begin{tabular}{|c|c|c|c|c|}
\hline \multirow[b]{2}{*}{ KKM } & \multirow[b]{2}{*}{$\begin{array}{l}\text { Jumlah } \\
\text { Siswa }\end{array}$} & \multicolumn{2}{|l|}{ Ketuntasan } & \multirow[b]{2}{*}{$\begin{array}{l}\text { Presentase } \\
\text { Ketuntasan }\end{array}$} \\
\hline & & Siswa Tuntas & $\begin{array}{ll}\text { Siswa } & \text { Tidak } \\
\text { Tuntas } & \end{array}$ & \\
\hline 70 & 17 & 11 & 6 & $64,71 \%$ \\
\hline
\end{tabular}

Berdasarkan data hasil belajar siswa di atas menunjukan peningkatan dari hasil observasi awal. Terdapat 11 siswa yang telah mencapai KKM dan ada 6 siswa yang masih belum mencapai KKM sebesar 70. presentase kelulusan yang dicapai oleh 17 siswa hanya mencapai $64,71 \%$ dengan rata-rata nilai hasil belajar Kognitif sebesar 72,5. Hasil belajar rata-rata siswa telah mencapai KKM tapi karena presentase ketuntasan tidak mencapai Ketuntasan Klasikal sebesar 75\%, maka perlu adanya pelaksanaan siklus II guna meningkatkan hasil belajar Kognitif Siswa. 
Candra, Asep, Penerapan Metode Group Investigation....

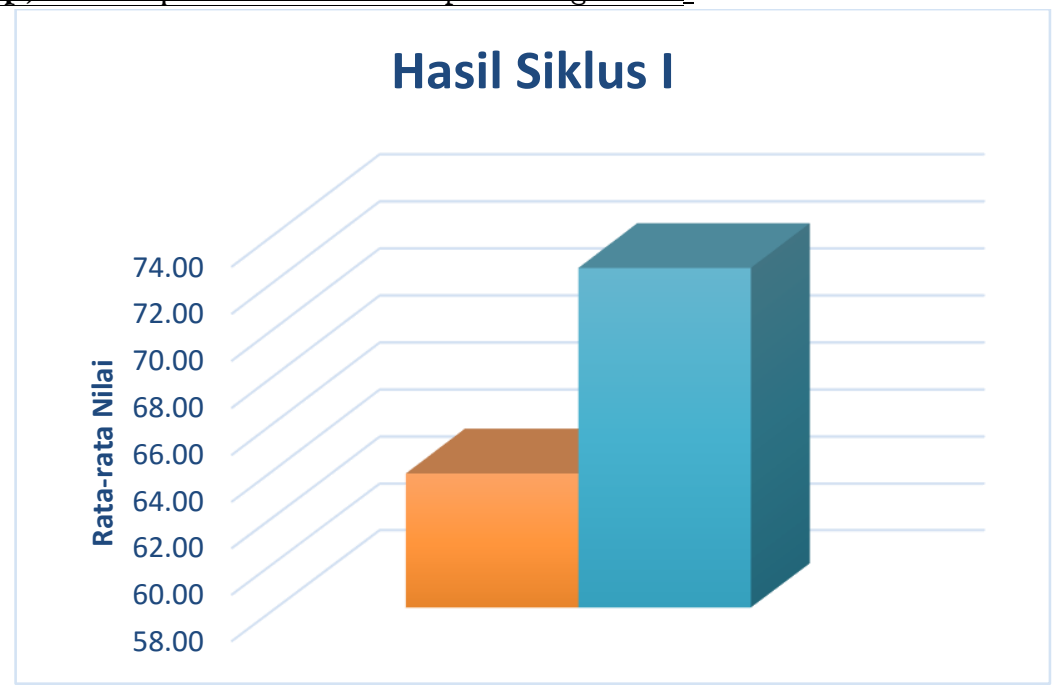

Diagram 1. Hasil Belajar Siklus I

Berdasarkan diagram di atas dapat dilihat terdapat peningkatan hasil belajar kognitif pada siklus I dibandingkan dengan hasil belajar prasiklus. Prasiklus siswa mendapakan nilai rata-rata 63,76 dimana terjadi peningkatan 8,74 poin menjadi 72,5 . Peningkatan cukup baik dari hasil belajar siswa tetapi belum cukup dalam mencapai target ketuntasan klasikal kelas.

\section{Tabel 4}

\section{Hasil Belajar Afektif}

\begin{tabular}{|l|l|l|l|l|}
\hline \multirow{2}{*}{ KKM } & \multirow{2}{*}{$\begin{array}{l}\text { Jumlah } \\
\text { Siswa }\end{array}$} & \multicolumn{2}{|l|}{ Ketuntasan } & Presentase \\
\cline { 2 - 4 } & Siswa Tuntas & Siswa Tidak Tuntas & Ketuntasan \\
\hline 70 & 17 & 5 & 12 & $29,41 \%$ \\
\hline
\end{tabular}

Tabel di atas menunjukan hasil belajar Afektif siswa kelas VI SD Penerus Bangsa selama pelaksanaan siklus I. Terdapat 5 siswa yang mendapatkan predikat tuntas dalam melaksankana pembelajaran siklus I sedangkan 12 siswa lain belum mencapai predikat tersebut. Presentase ketuntasan yang dicapai siswa sebesar 29,41\% masih sangat jauh dari presentase ketuntasan klasikal sebesar 75\%. Berdasarkan hasil tersebut maka perlu adanya pelaksanaan siklus II guna meningkatkan hasil belajar Afekti siswa sehingga dapat mencapai ketuntasan klasikal. 
Candra, Asep, Penerapan Metode Group Investigation...

\section{Tabel 5}

Hasil Belajar Psikomotor

\begin{tabular}{|l|l|l|l|l|}
\hline \multirow{2}{*}{ KKM } & $\begin{array}{l}\text { Jumlah } \\
\text { Siswa }\end{array}$ & Setuntasan & Presentase \\
\cline { 3 - 5 } & 17 & 17 & $\begin{array}{l}\text { Siswa Tuntas } \\
\text { Tuntas }\end{array}$ & Tidak \\
\hline 70 & 17 & 0 & $100,00 \%$ \\
\hline
\end{tabular}

Berdasarkan tabel hasil belajar psikomotor siswa di atas menunjukan siswa yang mencapai ketuntasan belajar sebanyak 17 siswa. Pelaksanaan praktik pembuatan produk teropong sederhana menunjukan siswa dapat bekerja sama dengan baik dalam membuat produk sesuai dengan instruksi yang telah diberikan. Presentase ketuntasan hasil belajar psikomotor sebesar $100 \%$ menunjukan siswa sangat antusias dalam melaksanankan pembelajaran.

Temuan dalam penelitian yang dilaksanakan di SD Penerus Bangsa Kecamatan Periuk Kota Tangerang, adalah adanya peningkatan hasil belajar tiga aspek penilaian belajar siswa pada meteri Sistem Tata Surya. Perubahan cara serta peningkatan hasil belajar dirasakan siswa selama melaksankaan pembelajaran siklus I dapat dijabarkan sebagai berikut : (1) Rata-rata hasil belajar konitif siswa dari 63,76 menjadi 72,5. (2) Rata-rata hasil belajar afektif sebesar 61,76 dengan presentase ketuntasan sebesar 29,41\%. Menjadi tolak ukur aktivitas kegiatan belajar siswa. (3) Rata-rata hasil belajar psikomotor siswa sebesar 87,06 dengan presentase ketuntasan sebesar $100 \%$.

Kegagalan siswa mencapai ketuntasan kognitif disebabkan oleh beberapa faktor yaitu : (1) kurang aktifnya siswa dalam sesi tanya jawab sehingga materi pembelajaran tidak terbahas secara mendalam. (2) Sikap individualisme siswa terlihat karena kurangnya kerjasama antar kelompok dalam membahas dan memperdalam pemahaman materi pembelajaran. (3) proses investigasi yang tidak optimal sehingga membuat kelompok tidak menguasai materi dengan baik, serta menyebabkan kelompok lain tidak secara maksimal mendapatkan materi. Faktor diatas menunjukan sikap apatis siswa karena belum terbiasa melaksankan pembelajaran secara mandiri. Peningkatan rata-rata hasil belajar menjadi 72,5 tidak membuat penilaian hasil belajar kognitif dihentikan karena belum mencapai presentase ketuntasan klasikal sebesar $75 \%$.

Kegagalan hasil belajar afektif juga menjadi temuan penelitian siklus I dan terdapat beberapa faktor yang menyebabkan hal tersebut antara lain : (1) Kurangnya 
Candra, Asep, Penerapan Metode Group Investigation...

parsipasi siswa dalam membahas secara tuntas selama sesi tanya jawab berlangsung. Menunjukan siswa belum terbiasa untuk aktif dalam melaksankaan pembelajaran. (2) Kurangnya diskusi kelompok juga menjadi kendala dalam melaksankana investigasi sehingga investigasi yang dilaksanakan tidak berjalan dengan baik (3) kreatifitas yang tidak berkembang dalam menyajikan laporan hasil investigasi juga menyulitkan siswa dalam berkomunikasi dengan siswa lain sehingga materi presentasi tidak tersampaikan dengan baik. (4) Rasa percaya diri yang kurang menjadi faktor penting bagaimana siswa belum secara nyaman melaksanakan pembelajaran terutama pada sesi presentasi karena siswa belum terbiasa dengan pembelajaran mandiri dan pemaparan laporan.

Berbeda dengan hasil belajar kognitif dan afektif, hasil belajar psikomotor menjadi aspek yang mendapatkan keberhasilan pada siklus I. Faktor yang mempengaruhi keberhasilan hasil belajar psikomotor sebagai berikut : (1) Dikerjakan secara berkelompok. Pekerjaan dilakukan secara berkelompok membuat siswa yang kurang menjadi ikut naik bersama dengan siswa yang memiliki kelebihan. (2) Instruksi dan proses pembuatan yang sudah sangat jelas dapat dilaksanakan dengan baik oleh setiap kelompok.

Hasil penelitian Siklus II mendapatkan hasil belajar yang didapatkan peneliti sajikan dalam bentuk tabel dengan rekapitulasi data sebagai berikut :

\section{Tabel 6}

\section{Hasil Belajar Siklus II}

\begin{tabular}{|l|l|l|l|}
\hline No. & Aspek Penilaian & Rata-rata nilai & \multirow{2}{*}{ Rata-rata Nilai Akhir } \\
\hline 1 & Kognitif & 83,09 & \multirow{2}{*}{83,64} \\
\hline 2 & Afektif & 84,19 & \\
\cline { 1 - 2 } JUMLAH & 167,28 & \\
\hline
\end{tabular}

Berdasarkan tabel di atas peneliti menunjukan nilai rata-rata hasil belajar Kognitif dan Afektif yang didapatkan selama pelaksanaan siklus II. Hasil belajar Kognitif yang didapatkan 17 siswa yang telah dirata-ratakan adalah 83,64 naik sebesar 10,59 poin dibandingkan dengan siklus I, dan kenaikan sebesar 19,33 poin jika dibandingkan dengan hasil belajar prasiklus. Kenaikan juga terjadi pada hasil belajar Afektif 22,43 poin jika dibandingkan dengan hasil yang didapatkan pada siklus I. 
Candra, Asep, Penerapan Metode Group Investigation...

Tabel 7

Hasil Belajar Kognitif Siklus II

\begin{tabular}{|l|l|l|l|l|}
\hline \multirow{2}{*}{ KKM } & \multirow{2}{*}{ Jumlah Siswa } & \multicolumn{2}{|l|}{ Ketuntasan } & $\begin{array}{l}\text { Presentase } \\
\text { Ketuntasan }\end{array}$ \\
\cline { 3 - 5 } & & Siswa Tuntas & $\begin{array}{l}\text { Siswa Tidak } \\
\text { Tuntas }\end{array}$ & $100,00 \%$ \\
\hline 70 & 17 & 17 & 0 & 17 \\
\hline
\end{tabular}

Dilihat dari tabel di atas terdapat 17 siswa yang mencapai ketuntasan belajar pada siklus II dari total 17 siswa kelas VI. Presentase ketuntasan yang didapatkan dari 17 siswa yang tuntas adalah 100,00\% naik sebesar 35,29\% jika dibandingkan dengan hasil belajar yang didapatkan pada siklus I. Ditinjau dari ketuntasan klasikal sebesar $75 \%$ maka presentasi hasil belajar yang didapatkan pada siklus II ini dapat dikatakan berhasil.

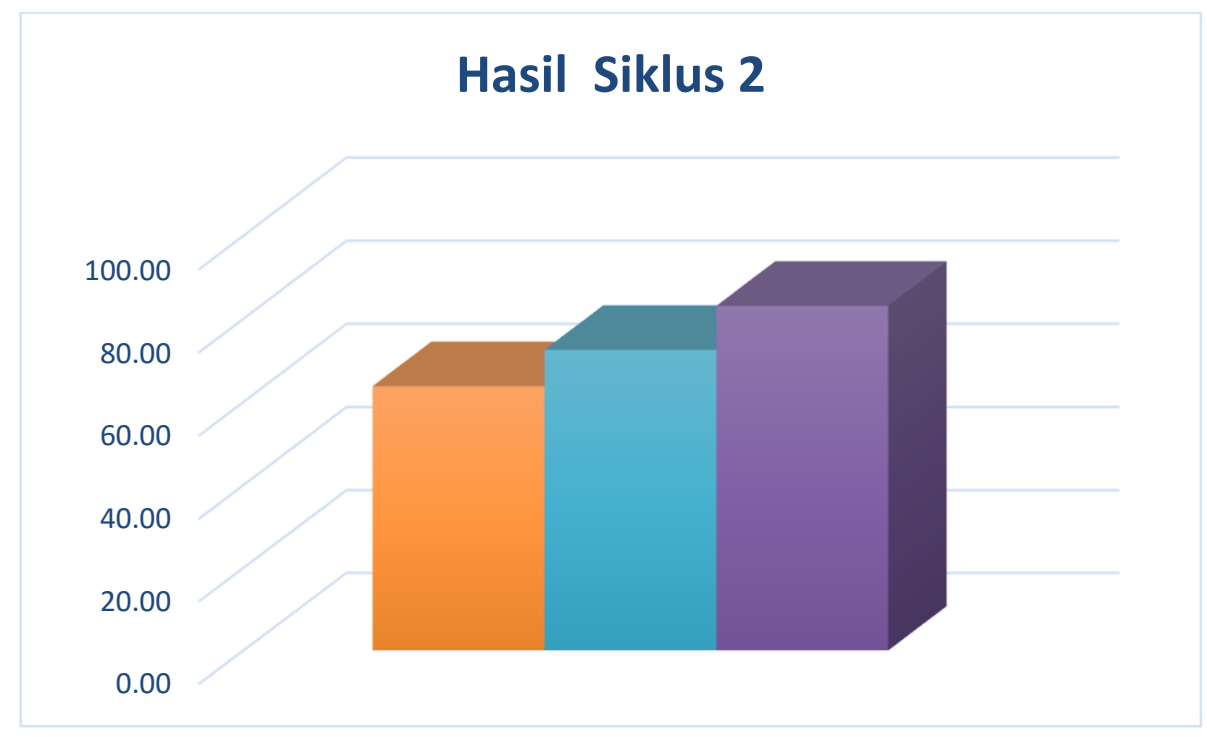

Diagram 2.Hasil Belajar siklus II

Berdasarkan diagram di atas dapat dilihat terdapat peningkatan hasil belajar kognitif pada siklus II dibandingkan dengan hasil belajar prasiklus. Prasiklus siswa mendapakan nilai rata-rata sebesar 63,76 dimana terjadi peningkatan sebesar 19,33 poin menjadi 83,09 jika dibandingkan dengan hasil belajar siklus II, serta naik sebesar 10,59 poin jika dibandingkan dengan hasil belajar siklus I. Peningkatan kearah yang baik dari hasil belajar siswa dan telah melampaui KKM yang Telah ditentukan.

Hasil belajar yang juga dinilai pada siklus II ini adalah hasil belajar Afektif. Tabel hasil belajar Afektif peneliti tuliskan sebagai berikut: 
Candra, Asep, Penerapan Metode Group Investigation...

\section{Tabel 8}

Hasil Belajar Afektif Siklus II

\begin{tabular}{|l|l|l|l|l|}
\hline \multirow{2}{*}{ KKM } & \multirow{2}{*}{ Jumlah Siswa } & \multicolumn{2}{|l|}{ Ketuntasan } & Presentase \\
\cline { 3 - 5 } & Siswa Tuntas & $\begin{array}{l}\text { Siswa } \\
\text { Tuntas }\end{array}$ & Tidak & \begin{tabular}{l} 
Ketuntasan \\
\hline 70
\end{tabular} \\
\cline { 3 - 5 } & 17 & 17 & 0 & $100,00 \%$ \\
\hline
\end{tabular}

Berdasarkan tabel hasil belajar Afektif di atas terdapat 15 siswa yang telah mencapai nilai KKM sedangkan 2 siswa lain masih belum mencapai standar tersebut. Presentase yang dicapai pada hasil belajar kognitif ini sebesar 100,00\% naik secara signifikan sebesar 70,59\% jika dibandingkan siklus I. Dilihat dari hasil belajar Afektif siklus II kriteria ketuntasan klasikal sebesar 75\% sudah tercapai dari sebanyak 17 siswa telah mencapai KKM mata pelajaran.

Berdasarkan hasil observasi pada siklus II ini didapatkan nilai rata-rata hasil belajar kognitif sebesar 83,09 dengan presentase kelulusan sebesar 100,00\%. Nilai ratarata hasil belajar afektif siswa sebesar 84,19 dengan presentase sebesar 100,00\%. Nilia rata-rata hasil belajar psikomotor siswa yang didapatkan pada siklus I sebesar 87,06 dengan presentase siswa lulus sebesar $100 \%$. Peningkatan hasil belajar serta aktivitas dan ketuntasan ketiga aspek penilaian sudah tercapai maka penelitian tindakan kelas dihentikan.

Temuan yang lain pada penelitian yang dilaksanakan pada kelas VI SD Penerus Bangsa Kecamatan Periuk Kota Tangerang, adalah adanya peningkatan kembali pada rata-rata hasil belajar kogntiif sebesar 83,09 dengan presentase ketuntasan klasikal sebesar $100,00 \%$. Peningkatan yang baik dengan selisih 10,56 poin pada rata-rata hasil belajar siklus I dan selisih 19,33 jika dibandingkan dengan prasiklus. Hasil belajar afektif juga mengalami peningkatan sebesar 84,19 dengan presentase ketuntasan klasikal sebesar 100,00\%. Penilaian hasil belajar psikomotor tidak dilaksanakan karena dianggap telah tuntas pada pelaksanaan siklus I.

Keberhasilan hasil belajar kognitif pada penelitian siklus II disebabkan beberapa faktor sebagai berikut : (1) Siswa telah nyaman dan lebih percaya diri dalam melaksanakan pembelajaran. Rasa percaya diri dibutuhkan untuk presentasi hasil investigasi yang menentukan bagus atau tidaknya penampilan kelompok. (2) Kreatifitas siswa sangat terlihat terutama dalam menyajikan media laporan. Siswa sangat terbantu 
Candra, Asep, Penerapan Metode Group Investigation...

dalam mempresentasikan materi investigasi, sehingga proses pembelajaran berjalan lebih menarik. (3) Kerjasama tiap kelompok sudah sangat terlihat dengan hasil penguasaan materi pembelajaran. Kerjasama akan memicu dan menaikan semangat siswa yang kurang secara akademik untuk lebih semangat dalam melaksakaan pembelajaran

Keberhasilan juga dicapai siswa pada hasil belajar afektif, yang menjadi faktor penentu keberhasilan yaitu : (1) Reward yang diberikan memacu siswa dalam melaksanakan pembelajaran. Pemberian hadiah kepada kelompok terbaik memberikan lecutan kepada setiap kelompok untuk menampilkan dan mengikuti pembelajaran dengan sangat baik. (2) Meningkatnya kemampuan dalam menggunakan kalimat membantu siswa dalam berkomunikasi dan menyampaikan materi investigasi. (3) Pertanyaan siswa yang lebih variatif, siswa juga mendapatkan perkembangan daya kritis dalam membuat pertanyaan sebagaimana karakter yang diharapkan pada kurikulum 2013 revisi.

\section{SIMPULAN}

Kesimpulan yang dapat diambil setelah melaksanakan penelitian dengan menggunakan metode pembelajaran Group Investigation materi Sistem Tata Surya di kelas VI SD Penerus Bangsa Kecamatan Periuk Kota Tangerang adalah bahwa keberhasilan pembelajaran IPA pada materi sistem tata surya menggunakan metode pembalajara Group Investigation didukung dengan meningkatnya berbagai aktivitas belajar siswa yang mandiri, kreatif dan berkembangnya kemampuan halus, nilai ratarata hasil belajar kognitif 83,09 dari KKM yang ditetapkan sebesar 70 dengan presentase ketuntasan belajar siswa sebesar 100,00\%. Ketuntasan hasil belajar afektif juga dicapai siswa dengan rata-rata nilai sebesar 84,19 dan presentase ketuntasan afektif sebesar $100,00 \%$. Nilai rata-rata hasil belajar psikomotor juga mencapai ketuntasan sebesar 87,06 dan presentase ketuntasan belajar siswa sebessar 100,00\%. Pelaksanaan pembelajaran menggunakan metode group Investigation (GI) dapat dikategorikan berhasil karena seluruh siswa dapat melampaui KKM serta memenuhi aspek kognitif, afektif dan psikomotor. Kesimpulan dari penelitian ini yaitu metode pembelajaran Group Investigation (GI) dapat meningkatkan hasil belajar IPA materi sistem tata surya kelas VI SD Penerus Bangsa Kecamatan Periuk Kota Tangerang. 
Candra, Asep, Penerapan Metode Group Investigation...

\section{SARAN}

Berdasarkan hasil yang didapatkan pada penelitian ini disarankan beberapa hal yaitu: (1) Guru, hendaknya lebih kreatif dalam menerapkan metode pembelajaran dengan menggunakan metode group Investigation guna menumbuhkan kemampuan halus dan kreatifitas siswa, serta meningatkan aktivitas belajar siswa dalam pembelajaran sistem tata surya, sehingga dapat meningkatkan hasil belajar kognitif, afektif, psikomotor dan kualitas pendidikan. (2) Bagi siswa, hndaknya lebih aktif dalam melaksanakan pembelajaran dan berusaha lebih baik lagi guna mendapatkan pengalaman belajar yang lebih bermakna sehingga dapat meningkatkan kemampuan dan hasil belajar siswa. (3) Bagi Kepala Sekolah, hendaknya menggunakan lebih aktif, kreatif dan inovatif dalam mengimplementasikan metode pembelajaran, sehingga dapat meningkatkan mutu, kualitas dan sistam pembelajaran yang pada akhirnya meningkatkan citra sekolah kearah yang lebih baik. (4) Bagi pengguna Metode Pembelajaran Group Investigation (GI) hendaknya menambahkan atau mengawasi alat peraga atau media yang digunakan untuk siswa sehingga siswa dapat dengan mudah menyampaikan hasil laporan investigasi di depan kelas.

\section{DAFTAR PUSTAKA}

Al-Tabani, T.I.B. 2014. Mendesain Model Pembelajaran Inovatif, Progresif, dan Kontekstual. Jakarta: Prenadamedia Group.

Arikunto, Suharsimi. 2015. Dasar-Dasar Evaluasi Pendidikan. Jakarta: Bumi Aksara.

Aunurrahaman. 2014. Belajar dan Pembelajaran. Bandung: Alfabeta.

Huda, M. 2014. Model-Model Pengajaran dan Pembelajaran. Yogyakarta: Pustaka Pelajar.

Muslich, M. 2012. Melaksanakan PTK (Penelitian Tindakan Kelas) itu Mudah. Jakarta: Bumi Aksara.

Rusman. 2012. Model-Model Pembelajaran. Jakarta: Raja Grafindo Persada.

Shoimin, A. 2014. 68 Model Pembelajaran Inovatif dalam Kurikulum 2013. Yogyakarta: ArRuzz Media.

Slavin, R. E. 2015. Cooperative Learning: Teori, Riset, dan Praktik. Bandung: Nusa Media. 
Candra, Asep, Penerapan Metode Group Investigation...

Suprijono, A. 2009. Cooperative Learning: Teori dan Aplikasi PAIKEM. Yogyakarta: Pustaka Pelajar.

Wisnawa, I. D. G. R. 2016. Penerapan Model Pembelajaran GI (Group Investigation) Untuk Meningkatkan Hasil Belajar IPA Kelas IV. Skripsi. Singaraja: Universitas Pendidikan Ganesha.

Yeni, M. A. 2016. Penerapan Model Pembelajaran Kooperatif Tipe Group Investigation Untuk Meningkatkan Hasil Belajar IPA Siswa Kelas IV SD Negeri 1 Siliwangi. Skripsi. Lampung: Universitas Lampung.

Yunanda, N. S. 2014. Penerapan Model Pembelajaran Kooperatif Tipe Group Investigation Berbasis Lingkungan Untuk Meningkatkan Aktivitas Belajar IPA Pada Siswa Kelas IV SD Negeri 1 Sugihmanik. Skripsi. Surakarta: Universitas Muhammadiyah Surakarta. 